Charter Rights and Public Policy Choices:

\title{
The Supreme Court and Public Finance
}

\section{Hugh Mellon}

\section{Introduction}

Over the past two decades there have been numerous highly charged court cases involving claims that government program offerings and public spending fail to satisfy guarantees entrenched in the Canadian Charter of Rights and Freedoms. ${ }^{1}$ Calls for enhanced appeal mechanisms in refugee determination, ${ }^{2}$ provincial health care coverage of hospital translation services for the deaf, ${ }^{3}$ equal leave provisions ${ }^{4}$ for both adoptive and birth parents, government coverage of autism treatment regimes, ${ }^{5}$ and access to health care provision rather than access to a waiting list ${ }^{6}$ all illustrate theintersection of the Charterwith theallocation of the public purse. Government cries about fiscallimits and competing choices do not always prevail; judicial reasoning in these cases is often complicated and sometimes inconsistent. Reexamination of this jurisprudence is imperative in light of growing national debates over health care spending and program delivery as well as over judicial scrutiny of government. ${ }^{7}$

The judges of the Supreme Court of Canada addressed a case that was relevant to these issues in Newfoundland (Treasury Board) v. N.A.P.E. ${ }^{8}$ They were called upon to assess the demands of governmental financial exigency relative to prior government commitments to equal treatment via payments designed to remedy gender-based pay differentials according to an agreed-upon timetable.
At issue were competing claims to primacy arising from an executive assertion of a public finance emergency and a union assertion of Charter-based demands for equal treatment of female public employees. In its decision the Court sided with the Newfoundland and Labrador government and its assertion that the public finance case must prevail. Justice Ian Binnie wrote the judgment on behalf of a unanimous Court. While that judgment resolved the case at hand, the judicial reasoning and commentary left room for significant future discussions. The Court's reasoning tolerates a surprising degree of discretion for a political executive to declare financial necessity and is vague about the guidelines for applying the relevant words "crisis" and "emergency." Given the perseverance of federal and provincial government debts, not to mention the possibilities of future serious recessions or depressions, it would be prudent to foster larger debate and examination of Justice Binnie's reasoning and its implications for balancing Charter rights with fundamental constraints.

Contemporary debates about the existence and nature of an institutional "dialogue" between courts and legislatures " reflect competing perspectives on the "dialogue" metaphor. However, a common theme is that the Supreme Court uses its decisions to alert the legislature to dangerous actions or decisions, and that the legislature may then respond. In the words of Kent Roach, "[T]he Court, assisted by the efforts of aggrieved litigants, starts the conversation by drawing 
the attention of the legislature to fundamental values that are likely to be ignored or finessed in the legislative process." 10 In Newfoundland v. N.A.P.E., the opposite scenario played out the Government of Newfoundland persuaded the Court that its financial fundaments could not be "ignored or finessed." For a variety of reasons there must be more examination and analysis of instances where declarations of public finance needs prevail. First, the literature about such situations is lacking. Second, there are various commentators suggesting a judicial retreat from the judgments of Supreme Courts past that upheld the Charter. Sheila McIntyre, for example, has recently asserted "that some members of the Court, including the Chief Justice, are trying to appease critics of socalled judicial activism by retreating from the Dickson-Lamer legacy." "11 Further examination of the N.A.P.E. decision will assist in the broader discussions over dialogue and alleged judicial retreat.

It will be argued that the judgment, while clear on the disposition of the case before it, is vague in regard to several potentially important matters. These matters include the operational definition of "crisis" and "emergency," the extent of the governmental evidence required to prove a crisis or emergency, and the task of balancing rights with finances according to the wording of some related past decisions; all leave more room for speculation than might seem prudent in an important institutional dialogue. Attention should also turn to the significance of the financial amounts involved in a rights claim and delineating the principled basis for the Supreme Court's apparent favouring of less expensive claims. Questions persist about who should get to calculate, what is considered less expensive (and therefore more likely affordable), and how to establish the correct approach to this calculation.

In Constitutional Odyssey, Peter Russell suggests that Canada is returning to "constitutional normalcy" after several decades of absorption in a quest for grand constitutional agreements. ${ }^{12} \mathrm{He}$ declares that "Canadians have shifted gears and fallen back on older, quieter, less conflictual, and more piecemeal ways of adjusting and adapting their constitutional system." ${ }^{\prime 3}$ In this quieter period of adjustment there exists an opportunity to review the deeper issues raised by the judicial reasoning in N.A.P.E. Better we think about these issues now than in a period of deep economic malaise.

\section{The Case of Newfoundland (Treasury Board) v. N.A.P.E.}

The central issue raised in Newfoundland (Treasury Board) v. N.A.P.E. is actions taken by the Government of Newfoundland in 1991 in responding to public finance challenges arising in part from an unexpected shortfall in federal fiscal transfers. This same government had several years earlier agreed to address incrementally, over a number of years, pay inequities endured by female health care employees. On 24 June 1988, an agreement was struck involving the provincial government and various public sector unions covering affected female employees. The assessment of the size of the inequity took longer than expected, and it was not completed until early 1991. At that time, the estimated cost of implementing the agreement was $\$ 24$ million.

Coincident with the completion of these calculations was the already-noted major shortfall in provincial finances. The Newfoundland government responded by passing the Public Sector Restraint Act, ${ }^{14}$ which contained a provision to delay implementation of the pay equity award. It cancelled payments for the period starting 1 April 1988 until 31 March 1991, thus negating the just-calculated \$24 million in payments. The incremental salary adjustments were also altered so that the first adjustment would not be 1 April 1988, but rather 31 March 1991. Ultimately, affected employees were left without the anticipated reimbursement money for 1988 to 1991. Grievances emerged that led ultimately to the Supreme Court case discussed in this article. While the case edged its way through the courts, the provincial government and the Newfoundland and Labrador Association of 
Public and Private Employees worked out a revised pay equity arrangement in accordance with the government restraint legislation. ${ }^{15}$

The union complaint went forth through various stages. The dispute was carried on through an Arbitration Board, the Newfoundland Supreme Court, Trial Division, and the Newfoundland Supreme Court, Court of Appeal before landing on the Supreme Court of Canada's doorstep. ${ }^{16}$ The Chief Justice of the Supreme Court of Canada set out three constitutional questions arising from the case on 29 October $2003 .{ }^{17}$ The first asked if the provision mandating the cancellation and adjustment of the pay equity benefits violated the equality rights in section 15(1) of the Charter of Rights and Freedoms. ${ }^{18}$ This led to the second question - if an infringement was found to exist, would it constitute a reasonable limit meeting the conditions of section 1 of the Charter? The third question related to an element in the Newfoundland Court of Appeal judgment calling for courts to explicitly recognize the separation of governmental powers doctrine at each stage of section 1 analysis. This last point would, if accepted, have been an additional to the customary judicial assessment of section 1 set out in the Supreme Court's decision in R. $v$. Oakes. ${ }^{19}$

The following commentary will proceed through four sections. First, it will examine the judgment's treatment of the province's section 1 justification. Justice Binnie used charged terms like "crisis" and "emergency" without the imposition of a significant evidentiary burden on the Newfoundland government and without definitional rigour. Second, it will analyze Justice Binnie's comments on the amount of money involved in the legal dispute. Comparison will be made with the Eldridge case from British Columbia regarding services for deaf individuals, in order to draw out several apparent judicial assumptions. ${ }^{20}$ Third, it expands the comparison to other widely noted cases wherein the balancing of expenditures and Charter and/or other constitutional claims was involved. Justice Binnie asserts a clear and consistent lineage, albeit through reference to loaded words like "prohibitive," "crisis," and “emergency." Finally, a concluding portion will highlight the perceived limits in Justice Binnie's analysis and set out the need for further study of several important points that require broader attention and debate.

\section{What Constitutes a "Crisis"? Section 1 and Justice Binnie's Judgment}

Section 1 analysis involves judicial assessment using the Oakes Test. It was the task of the Supreme Court in this case to review the challenged legislation and the history of the case, going back to the initial debates at the Arbitration Board. ${ }^{21}$ There was the burden upon the government to make the case that their legislative objective was evident and pressing. Yet the government was not generous in providing supporting material. Justice Binnie himself acknowledges some difficulty with the government's case, describing their section 1 material as "casually introduced." 22 In his reasons, Justice Binnie upholds at length the provincial government's legislation but admits that its case had notable limitations. Furthermore, he appears to wish to judge the severity of the financial crisis and supplement the provincial justification. Taken together, Justice Binnie's concessions regarding the limitations of the province's presentation and the way in which he chose to characterize the state of provincial public finances undercut the clarity of the judgment and its usefulness as a precedent.

Complications begin with reference to the government's justification, the starting point of a section one analysis. Justice Binnie states:

The only evidence before the Board consisted of an extract from Hansard and some budget documents. The government witnesses were not employed in the relevant policy group at the time.

Ordinarily such a casually introduced s. 1 record would be a matter of serious concern. However the essential subject matter of the s.1 justification in this case consists of the public accounts of the Province that are filed with the House of Assembly, and comments by the Minister of Finance and the President of the 
Treasury Board as to what they thought the amounts disclosed and what they proposed to do about it, which are reported in Hansard. This is all material of which courts may take judicial notice.... ${ }^{23}$

Judicial notice is the principle that courts may accept matters that are obviously true and accurate - in N.A.P.E., judicial notice was taken that there was a financial crisis in the province. Whether financial crisis should have been assumed to be the issue in this case is not at all clear. Justice Binnie himself goes on to "agree with the Board that the government ought to have called witnesses who were better placed to explain the governmental accounts and ministerial observations" regarding Newfoundland's situation. ${ }^{24}$ However, the lack of clarity is manifested most dramatically in the various phrases chosen by Justice Binnie to describe the Newfoundland government's financial circumstances. This is especially important because the Court is not simply upholding a tribunal's or lower court's finding of a crisis. He instead asserts a crisis based on his own assessment of the situation.

There is a fundamental difference between accepting the accuracy of financial figures and accepting the alleged or presumed implications of those same figures. Justice Binnie, however, conflates these concepts in the course of his decision, despite his criticisms of the Newfoundland government's presentation of their evidence. He not only recognizes the figures offered by the Newfoundland government, but he also accepts, without expressing any doubt, that a public finance emergency situation existed that necessitated dramatic government action. The criteria for, or definition of, an emergency are neither stated nor established; rather, there is ready acceptance that one existed. Given the situation of affected workers and their loss of equity payments, it is striking that Justice Binnie required such a limited supporting case from the province.

Justice Binnie does make a distinction between so-called "normal" and "crisis" times:

The spring of 1991 was not a "normal" time in the finances of the provincial government. At some point, a financial crisis can attain a dimension that elected governments must be accorded significant scope to take remedial measures, even if the measures have an adverse effect on a Charter right, subject, of course, to the measures being proportional both to the fiscal crisis and to their impact on the affected Charter interests. In this case, the fiscal crisis was severe and the cost of putting into effect pay equity according to the original timetable was a large expenditure ( $\$ 24$ million) relative even to the size of the fiscal crisis. ${ }^{25}$

Justice Binnie thus asserts the existence of a "crisis" on the basis of his interpretation of the provincial government's presentation of financial information. He suggests that the "crisis" will impact on the provincial credit rating, government borrowing, and expenditure choices. ${ }^{26}$ His commentary suggests the Court is doing more than simply taking notice of a lower court finding of fact. He offers his own conclusion and sets out his train of thought.

The immediate questions for further debate are clearly evident. What are the legal prerequisites for something being called a "crisis," let alone an "emergency"? What are the other categories or economic labels? Is such a judgment within the purview of Justice Binnie's professional expertise in an instance where he himself admits that the government case is "casually" made? Delineating the definitional boundaries of a "crisis" is not attempted by the justice.

Over the course of the decision, Justice Binnie uses various phrases to set out his understanding of the condition of Newfoundland public finances in 1991. There is, in fact, reference to an even more charged phrase than "crisis" namely, "financial emergencies." He cautions that "the courts cannot close their eyes to the periodic occurrence of financial emergencies when measures must be taken to juggle priorities to see a government through the crisis." ${ }^{27}$ Justice Binnie reports that in reaching his assessment he considered potential job losses and the size of the financial amounts involved. ${ }^{28} \mathrm{He}$ also goes on to accept the Newfoundland government's reference to the province's financial hardship in 
the 1930s and relegation to trusteeship ${ }^{29}$ under a British Commission of Government until it joined confederation. ${ }^{30}$

Even if a lenient observer might accord the Court the opportunity to characterize something as a "crisis," it would be hard to make a similar case for "emergency." For most observers "emergency" would imply situations such as: a serious break-down in social order, loss of voting rights and the practice of selfgovernment as carried out for decades, the impending resignation of a government, widespread and uncontrolled contagion, uncontrolled crime, and/or the near absence of vital government services. Newfoundland public finances in 1991 were in complicated straits, but whether they truly approached "emergency" condition is not demonstrated in any kind of serious and sustained way in the Court's ruling.

There is earlier Canadian jurisprudence about the assertion of emergencies, primarily in relation to the "Peace, Order, and Good Government" clause of the Constitution Act, 1867. ${ }^{31}$ This jurisprudence addresses occasional federal government arguments that the clause gives it the right to act even in areas otherwise accepted as provincial jurisdiction. Perhaps the clearest case of such a disputed economic emergency relates to the Anti-Inflation Reference $^{32}$ in 1976. A majority of Supreme Court justices upheld the Trudeau government initiative to control prices and wages in order to stem inflationary pressures. Taken together, the judicial reasons on the questions raised by the case remain a source of legal controversy. Baier portrays it as "an ambivalent collage of reasons and dissents that offered no clear interpretation of POGG as a justification for the exercise of federal power in matters of national concern." ${ }^{33}$ Russell, Knopff, and Morton offer the following pithy critique of the judgments centralizing tendencies: "[T]he Court's willingness to sustain the Anti-Inflation Act as emergency legislation had frightening implications for the provinces." 34 Justice Binnie's use of the charged words "crisis" and "emergency" without definitional rigour shows a persistent judicial reluctance to enunciate underlying assumptions or perspectives on economic situations, a tendency that is particularly troubling in a contemporary era of debate about resource allocation and government policy options in fields such as health care delivery and child care.

\section{The Characterization of Costs: Comparison with Eldridge}

Justice Binnie's endorsement of the Newfoundland government's "crisis/ emergency" claim leads us to the question of the size of the financial amount at issue. At what financial point does a crisis start? How big do government expenditures have to be before they are contributing to a problem? What is the basis for evaluating possible expenditures at a time of crisis? These are all questions deserving of attention.

One element of the Oakes Test is that if a measure is justified in limiting a right under section 1 , the right may only be impaired in a minimal way. Deference to government plans is considered acceptable if there is evidence that minimal impairment was a major concern and alternatives to impairment were examined (assuming, of course, that adherence to the other parts of the Oakes Test). Efforts to weigh the degree of impairment will obviously require the Court to weigh governmental budgetary decisions. Assessment and measurement questions abound.

One way to illustrate the existence of seemingly alternative ways to approach these methodological challenges is to compare the analysis of Justice LaForest in Eldridge $e^{35}$ with that of Justice Binnie in N.A.P.E. Both cases involved government health and social service budgets, but they featured very different lines of reasoning. Whereas Justice Binnie first assessed the overall state of provincial finances, Justice LaForest considered the Charter guarantees of equality and the inequities that pervade society. Only then did Justice LaForest deal with the costs at issue, and he treated them as an isolated, separategroup of expenses. These fundamentally 
different strategies speak to a lack of clarity and offer alternative approaches rather than clear, generally applicable principles.

At issue in Eldridge was the denial of public funding for medical translation services for the hearing impaired. More specifically, the cases stemmed from a debate over provision of sign language interpreters for clients of the health care system. Without interpretation services, individuals without private access to interpreters encounter communication difficulties and may be vulnerable to serious misunderstandings. The severe difficulties experienced by people due to the lack of such services are obvious. Yet, the B.C. Court of Appeal found no requirement on the part of the provincial government to fund such translation services. Equality rights seen from this vantage point existed to ensure equal application of laws, rather than a more expansive understanding wherein government had a duty to act positively to make society more equal and just.

In the Supreme Court judgment, Justice LaForest wrote for a unanimous Court of the social challenges of deafness and the value of equality:

\footnotetext{
The evidence clearly demonstrates that, as a class, deaf persons receive medical services that are inferior to those received by the hearing population. Given the central place of good health in the quality of life of all persons in our society, the provision of substandard medical services to the deaf necessarily diminishes the overall quality of their lives. The government has simply not demonstrated that this unpropitious state of affairs must be tolerated in order to achieve the objective of limiting health care expenditures. ${ }^{36}$
}

This judgment evidences a broad-minded sense of equality, linking the right to ready availability of translation services with good health, quality of life, and equality. ${ }^{37}$

The respondents in Eldridge were the British Columbia Attorney General and the provincial Medical Services Commission. Among their arguments were financial pressures and cost issues. Justice LaForest was not sympathetic. When the respondents queried how the courts were to distinguish between translation services for the deaf from services for those who speak non-official languages, Justice LaForest dismissed the point as "purely speculative." 38 When the issue was raised of a possible "ripple" effect caused by the recognition of this claim in a sea of claims, he countered by declaring: "These arguments miss the mark." ${ }^{39}$ Justice LaForest found that "effective communication" for the hearing impaired was not only a vital precondition for enjoying guaranteed health services, it was also inexpensive, ${ }^{40}$ suggesting that the provincial government could not justify failing to pay such a small cost.

The ultimate point for the justices in Eldridge was their perception that medical translation services for the hearing impaired had a small price tag:

[T]he government has manifestly failed to demonstrate that it had a reasonable basis for concluding that a total denial of medical interpretation services for the deaf constituted a minimum impairment of their rights. As previously noted, the estimated cost of providing sign language interpretation for the whole of British Columbia was only $\$ 150,000$ or approximately 0.0025 percent of the provincial health care budget at the time. ${ }^{41}$

The implication is that the government was too stingy to fork over themeasly $\$ 150,000$. While this may or may not be a correct interpretation of the government's recalcitrance to provide the translation funding, the estimated amount is indeed far smaller than the amount involved in the Newfoundland pay equity dispute. However, our questions about how judges approach the making of such an assessment and whether the absolute a mount involved is the right foundation for this calculation persist.

We might be well advised to bear in mind the cautionary words offered by the Honourable Marshall Rothstein to the Faculty of Law at the University of Manitoba. Reflecting upon Eldridge, Justice Rothstein declares: "In assessing the financial implications, significant subjectivity often creeps into the court's minimum impairment analysis." ${ }^{2}$ The treatment of the translation costs as an isolated, stand-alone budget item concerns 
him. Troubling future possibilities might be put into play, as "Charter rights claimants may bring claims incrementally in order to avoid a significant comprehensive cost argument by the government." ${ }^{\prime 43}$ Justice Rothstein also cited the added justification burden placed upon governments if this situation were to come to pass. Proving that rights are infringed in a minimal fashion presumably would require a context with generally agreed-upon assumptions about costs and their calculation.

In N.A.P.E., Justice Binnie makes reference to the reasoning in Eldridge and the reliance upon the limited financial amount at issue. ${ }^{44}$ What distinguishes the Newfoundland case from the Eldridge approach is Justice Binnie's acceptance of a crisis situation. Government calculations at crisis times are to be accorded "a large 'margin of appreciation' within which to make choices." ${ }^{35}$ Working from his declaration of a crisis, Justice Binnie characterizes the government's response as "proportional." ${ }^{46}$ Such a description is built on an uncertain foundation. Bear in mind two critical points not resolved clearly by either of the two cases considered here. One is that the boundaries of what constitutes a financial crisis are not made clear. Second, at what point do costs of desired social spending programs cease to be understood as independent stand-alone spending increments?

It is time now to expand the analysis and look at a broader cross-section of Supreme Court judgments involving claims of constitutional infringement and consideration of the associated costs. The opening paragraph of this article made reference to several of these kinds of cases. Those seeking clear guiding principles, let alone the foundations of an institutional dialogue between the judiciary and the executive, will likely be frustrated.

\section{Further Comparisons}

In relation to the general issue of the judicial approach to government budgetary prerogatives, there are various cases that could be reviewed here. The point of drawing upon Eldridge in the previous section was to point to the existence of alternative approaches to the assessment of program costs. Attention now turns to a larger matter - the complicated history of jurisprudence regarding competing claims that emanate from budgetary necessities and Charter rights. In the mid-1980s, Justice Bertha Wilson had an opportunity to relate Charter and budgetary claims in the case of Singh $v$. Minister of Employment and Immigration. ${ }^{47}$ This case addressed a dispute over the requirements of justice in the context of immigration and refugee determinations. Government practices were challenged on the principle that the Charter should apply to people seeking entrance to Canada, and that it should be mandatory for hearings on this point to allow claimants to hear the case against them. Justice Wilson denounced the very idea that matters of cost and administrative convenience might triumph over rights:

Certainly the guarantees of the Charter would
be illusory if they could be ignored because it
was administratively convenient to do so. No
doubt considerable time and money can be
saved by adopting administrative procedures
which ignore the principles of fundamental
justice but such an argument, in my view,
misses the point of the exercise under s. $1 .^{48}$

Justice Wilson's only real expression of interest in cost and administrative factors comes near the end of her opinion. Justice Binnie refers us to this brief section as he attempts to find room within which to move away from the spirit of the bulk of the commentary in Singh. ${ }^{49}$ However, Justice Wilson's acknowledgement is grudging and the burden of proof is high: "Even if the cost of compliance with fundamental justice is a factor to which the courts would give considerable weight, I am not satisfied that the Minister has demonstrated that this cost would be so prohibitive as to constitute a justification with the meaning of s. $1 .{ }^{50}$ She then says that it would be "unwise" to speculate upon what that kind of situation would amount to sufficient justification. ${ }^{51}$

It is difficult to conceive of an institutional dialoguewhen thejudiciarycanavoid committing itself on what legal status accord "compliance cost" considerations. Bear in mind the phrases "even if" and "prohibitive." Presumably, there 
should be a benchmark for something that is not just onerous or demanding but, rather, "prohibitive." For the record, the Singh decision led not only to added administrative workload but also millions of dollars in added expenses. In the pithy words of Michael Mandel, "[W]hat Justice Wilson had contemptuously dismissed as mere 'administrative inconvenience' turned out to be an immense bureaucratic knot that would take millions of dollars and years of labour to untie." 52

Here, reference should be made to the arguments of Jeremy Clarke on the Court's sensitivity to federal considerations in the judicial assessment of N.A.P.E. and other cases. ${ }^{53}$ Newfoundland is not presented as simply any province enduring public finance concerns; Justice Binnie is aware that it is a province with a history of past problems and persistent fiscal weakness when compared to other provinces. Clarke points out "that if and when judges allow for a differential application of the Charter's national standards, they are responding to federalist interpretations of the Charter contained in provincial factums before the Court . . . " "54 The implications of this response and the emerging federalist dialogue cited by Clarke bears watching, for if this emerging trend continues, the framing of panCanadian Charter arguments will need to be far more nuanced.

Clarke senses a judicial willingness to let provincial communities sort out particular issues in distinctive ways. There is recognition of "the need or desire of provincial communities to build or sustain themselves based on their own conceptions of rights." 55 This is an illuminating argument, but in the Newfoundland case the provincial government rationale is much less about a developed conception of rights and more about the combination of a distinctive provincial history of financial limits coupled with recurring weakness. Given Justice Binnie's reprimand of the provincial government for sloppy section 1 presentation, the possibility of a developed provincial conception of rights being at work might be approached cautiously in this particular case.
Caution aside and the limits of the section 1 case noted, the value of Clarke's insights are seen perhaps most vividly in paragraph seventy-five of Justice Binnie's judgment, where he asserts that the provincial government had a range of difficult choices before it as to priorities and public needs:

The government in 1991 was not just debating rights versus dollars but rights versus hospital beds, rights versus layoffs, rights versus jobs, rights versus education and rights versus social welfare. Therequirement to reduceexpenditures, and the allocation of the necessary cuts, was undertaken to promote other values of a free and democratic society .... ${ }^{56}$

Those accustomed to portraying the courts as aloof from the complexities of administrative imperatives and tough political choices will draw comfort from these words. However, these trade-offs happen daily in the corridors of government. When are these governmental arguments compelling? What are the legal principles defining when deference to this governmental defence applies? Justice Binnie's judgment offers little in the way of a broader answer.

Apparent confusion about the proper approach toward financial factors and budget requirements is also seen in Auton (Guardian ad litem of) v. British Columbia (Attorney General) ${ }^{57}$ and Figueroa v. Canada (Attorney General). ${ }^{58}$ In the former case, families pursuing Medicare coverage of emerging autism treatments found themselves unseated at the Supreme Court after victories at earlier court levels. The B.C. government's policy choices about what treatments to cover were deemed non-discriminatory.

The Chief Justice set out the Court's understanding of the central issue, that the services sought were beyond those covered by the provincial health care system. Autism treatment, unlike translation services, was not seen as a precondition for taking advantage of services covered by the system. Instead, the request was for service expansion, allegedly beneficial but not approved for coverage, within the province of British Columbia: 
The issue is rather whether the British Columbia Government's failure to fund these services under the health plan amounted to an unequal and discriminatory denial of benefits under that plan, contrary to s. 15 of the Charter. Despite their forceful argument, the petitioners fail to establish that the denial of benefits violated the Charter. ${ }^{59}$

Clearly, attention is paid to whether or not there exists the denial of a legislated benefit under the B.C. Medicare arrangements. Cost data and the benefits of treatment for purposes of potential "effective communication" are not the issue. The issue is not what care should be provided, but rather whether a benefit is being denied that is legislatively set out for others.

The Court distanced itself from the ruling in Eldridge by asserting that "this case is concerned with access to a benefit that the law has not conferred." 60 Translation services, on the other hand, were understood as prerequisites for consultations with physicians and other already publicly insured health benefits. Whereas the ruling in Eldridge spoke of health and the quality of life, the decision in Auton narrowed in on legislative purpose and the complexities of defining a comparison group for analysis. ${ }^{61}$ While laws which gave a specific group inferior treatment were wrong, "a legislative choice not to accord a particular benefit absent demonstration of discriminatory purpose, policy or effect does not offend this principle and does not give rise to s. 15(1) review." ${ }^{\prime 2}$ Further, the Court pointed out that few provinces ensured the particular new treatments at issue at the time of the legal action, and that the case for the parents had not sufficiently acknowledged the "recent and emergent" nature of the treatment. ${ }^{63}$ Those seeking some consistency with the expansiveness of Eldridge are disappointed by the more circumscribed judicial outlook in Auton. Expectations of emphasis on the quality of life of autistic children under new treatment regimes are unsatisfied.

Meanwhile, in Figueroa a common issue was raised in very different circumstances. Governmental rules required political parties to field candidates in at least fifty electoral constituencies to retain the status of political party and the privileges that went with it. Reasons for the rule were to protect the integrity of the tax system (given that contributions to political parties and candidates were at the time given favourable tax advantages), and the efficiency of electoral administration. The common issue is the balance of financial and budgetary measures with constitutional and/or Charter concerns. At issue were measures that had applied over several elections and that had, up to the time of the court case, never been seriously challenged. Here again the lower court decision was overturned at the Supreme Court level. In this instance, the Supreme Court advocated an expanded notion of democratic rights. They went on to indicate that they were not persuaded by the arguments about protecting the tax system and budgetary necessities.

The cases discussed in this section vary from the N.A.P.E. case in a number of ways. What the cases have in common is how the Supreme Court balances financial imperatives and executive budget authority (taxes and spending) with claims of rights and/or constitutional requirements. The high court seems to apply a diverse set of approaches to this balancing task. As a result, it is difficult to understand the judicial message about how much autonomy government budgetary restraint may have in instances of budgetary matters or in making choices between Charter/constitutional requirements and budgetary trade-offs. Those searching for judicial direction in the form of a judicial-parliamentary dialogue face a judicial record open to a variety of interpretations; not so much a dialogue as a wait for the next instalment of a long-running serial.

\section{Concluding Observations}

In the N.A.P.E. case the Supreme Court found for the provincial government based on assumptions of "crisis" and "emergency." These labels were affixed despite a weak section 1 presentation by the government and the lack of definitional or measurement qualification. Concern over this uncritical acceptance of the government's position led in other cases to an examination of judicial reasoning where rights or constitutional requirements ran counter 
to budgetary and financial decisions of the executive. Reference to a number of these cases revealed the apparent co-existence of different ways of assessing the costs involved, as well as different ways of balancing out the financial and the constitutional and rights concerns. This raises questions about uncertain judicial guidance and the need for further national policy discussion. Given the prevailing rightsconsciousness that exists in Canada, and given the likelihood of continued tough government budgetary choices, more attention needs to be paid to the various elements of this judicial record. Most governments may now be in a period of increasing surpluses, but this should not lull us into avoiding the need to grapple with the Supreme Court's rulings and shifting approaches.

\section{Notes}

* Hugh Mellon, PhD, Associate Professor, Department of Political Science, King's University College at The University of Western Ontario, hmellon@uwo.ca. The author would like to note the helpful advice offered by Prof. S. Noel, as well as the editor and reviewers for this journal. The research for this article has been assisted by the King's University College, at The University of Western Ontario, Research Fund.

1 Canadian Charter of Rights and Freedoms, Part I of the Constitution Act, 1982, being Schedule B to the Canada Act 1982 (U.K.), 1982, c. 11 [Charter].

2 Singh v. Minister of Employment and Immigration, [1985] 1 S.C.R. 177, 1985 CanLII 65 [Singh].

3 Eldridge v. British Columbia (Attorney General), [1997] 3 S.C.R. 624, 1999 CanLII 327 [Eldridge].

4 Schachter v. Canada, [1992] 2 S.C.R. 679, 1992 CanLII 74.

5 Auton (Guardian ad litem of) v. British Columbia (Attorney General), 2004 SCC 78, [2004] 3 S.C.R. 657, (CanLII) [Auton].

6 Chaoulli v. Quebec (Attorney General), 2005 SCC 35, [2005] 1 S.C.R. 791 (CanLII).

7 Canadian students of public finance and government administration have paid increasing attention in recent years to the political challenge of deficit reduction and debt management, but have often given only limited attention to the administrative implications of judicial decisions. An exception is Leslie A. Pal, Beyond Policy Analysis: Public Issue Management in Turbulent Times (Scarborough: ITP Nelson, 1997), which offers helpful insights. See, e.g., at 48-54. More scrutiny of how contemporary courts assess public finance limitations within their overall weighing of rights and duties is needed.

82004 SCC 66, [2004] 3 S.C.R. 381 (CanLII) [N.A.P.E.].

9 See Kent Roach, "Constitutional and Common Law Dialogues Between the Supreme Court and Canadian Legislatures" (2001) 80:1 \& 2 Canadian Bar Review 481.

10 Ibid. at 530-31.

11 "The Supreme Court and Section 15: A Thin and Impoverished Notion of Judicial Review" (2006) 31:2 Queen's Law Journal 731 at 767. Also see n. 114 at 767.

12 Peter H. Russell, Constitutional Odyssey: Can Canadians Become a Sovereign People?, 3d. ed. (Toronto: University of Toronto Press, 2004) at 272.

13 Ibid. at 272.

14 Public Sector Restraint Act, S.N. 1991, c. 3, s. 9, as rep. by Public Sector Restraint Act, 1992, S.N. 1992 , c. P-41.1.

15 N.A.P.E., supra note 8 at para. 10.

16 Newfoundland (Treasury Board) v. Newfoundland Association of Public Employees, 162 Nfld. \& P.E.I.R. 1 (Nfld. T.D.), aff'd 2002 NLCA 72, 220 Nfld. \& P.E.I.R. 1 (N.L. C.A.), online: CanLII <http://www.canlii.ca/nl/cas/nlca/2002/ 2002nlca72.html >, leave to appeal to S.C.C. granted, [2003] 1 S.C.R. xiv.

17 Supra note 8 at para. 29.

18 Supra note 1.

19 [1986] 1 S.C.R. 103, 1986 CanLII 46. In N.A.P.E., the Supreme Court judgment is unsympathetic to the Court of Appeal arguments over the addition of a separation of powers element to their section 1 analysis. The "Oakes Test" refers to the approach suggested by former Chief Justice Dickson to the assessment of governmental recourse to section 1 . Basically, they assume that infringements of Charter rights must relate to the actual achievement of serious governmental objectives, and that the limits on rights be carefully considered, minimal, and proportional to the significance of the governmental objective. Reference might be made to the commentary offered by Peter H. Russell, Rainer Knopff \& Ted Morton, Federalism and the Charter: Leading Constitutional Decisions, new ed. (Ottawa: Carleton University Press, 1989) at 452-53 [Russell, Knopff \& Morton].

20 Supra note 3.

21 N.A.P.E., supra note 8 at para. 58.

22 Ibid. at para. 56. 
23 Ibid. at paras. 55-56.

$24 \mathrm{Ibid}$. at para. 58.

25 Ibid. at para. 64.

26 Ibid. at paras. 60, 75 .

27 Ibid. at para. 72.

28 Ibid. at paras. 72,75

$29 \mathrm{Ibid}$. at para. 75.

30 See Melvin Baker, "The Tenth Province: Newfoundland Joins Canada" (1987) 10:111 Horizon 2641.

31 Constitution Act, 1867 (U.K.), 30 \& 31 Vict., c. 3, reprinted in R.S.C. 1985, App. II, No. 5, s. 91 [POGG].

32 Re: Anti-Inflation Act, [1976] 2 S.C.R. 373, 1976 CanLII 16.

33 Gerald Baier, "Judicial Review and Canadian Federalism" in Herman Bakvis \& Grace Skogstad, eds., Canadian Federalism: Performance, Effectiveness, and Legitimacy (Don Mills: Oxford University Press, 2002) 24 at 26.

34 Russell, Knopff \& Morton, supra note 19 at 163.

35 Eldridge, supra note 3.

36 Ibid. at para. 94.

37 For elaboration, see Bruce Porter, "Beyond Andrews: Substantive Equality and Positive Obligations After Eldridge and Vriend" (1998) 9:3 Constitutional Forum Constitutionnel 71.

38 Eldridge, supra note 2 at para. 89.

39 Ibid. at para. 92.

40 Ibid. at para. 92.

41 Ibid. at para. 87.

42 "Section 1: Justifying Breaches of Charter Rights and Freedoms," (2000) 27:2 Manitoba Law Journal 179.

43 Ibid. at 181.

44 Supra note 8 at paras. $83,84,87$.

45 Ibid. at para. 84 .

46 Ibid. at para. 85.

47 Supra note 1.

48 Ibid. at 218-19.

49 N.A.P.E., supra note 8 at para. 66.

50 Singh, supra note 2 at para. 73.

51 Ibid.

52 Michael Mandel, The Charter of Rights and the Legalization of Politics in Canada, rev. ed. (Toronto: Thompson Educational Publishing, 1994) at 243.

53 "Beyond the Democratic Dialogue, and Towards a Federalist One: Provincial Arguments and Supreme Court Responses in Charter Litigation" (2006) 39:2 Canadian Journal of Political Science 293.

54 Ibid. at 296.

55 Ibid. at 311.

56 N.A.P.E., supra note 8 at para. 75.
57 Supra note 5.

582003 SCC 37, [2003] 1 S.C.R. 912 (CanLII).

59 Auton, supra note 5 at para. 2.

60 Ibid. at para. 38.

61 Ibid. at paras 48-56.

62 Ibid. at para 41.

63 Ibid. at para 56. 